\title{
Enhancing judicial cooperation in civil matters through interactive language training
}

\section{Cecilia Holmsten ${ }^{1}$}

Published online: 31 August 2016

(C) ERA 2016

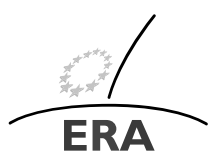

EUROPÄISCHE RECHTSAKADEMIE

ACADEMY OF EUROPEAN LAW ACADEMIE DE DROIT EUROPEEN ACCADEMIA DI DIRITTO EUROPEO
TRIER - TREVES - TREVIRI

European citizens are increasingly getting involved in cases with cross-border elements. During a trip abroad, a French holiday maker could have been involved in an accident or a Swedish mother could have taken her child with her to settle down in Spain, without the consent of the father. As citizens are increasingly using their rights of free movement for persons, goods, services and capital, cross-border disputes have been steadily increasing in number during the last few years. To make sure that citizens and businesses can truly enjoy the rights to which they are entitled to and to ensure the effectiveness of the internal market, the EU Commission has stressed that it is essential that the Member States empower citizens and businesses. It is important that the individual rights of citizens are protected, that cross-border litigation is facilitated, and that decisions can be recognized across the EU without any additional procedures. ${ }^{1}$ As it is now, more than ever before, likelier for an EU citizen to come before a foreign court, it is crucial to train national legal practitioners in how to correctly apply the various EU legal instruments and to deal efficiently with such cases. Through this, a genuine European area of justice can be upheld.

Therefore, the role of national judges and other legal practitioners is critical in the shaping of a genuine European area of justice. They need to be familiar with the existing EU acquis and to also be able to apply it in a correct and consistent manner. During the last fifteen years, there has been a steady increase in the number of legal instruments at EU level in civil and commercial matters, resulting in a lack of

\footnotetext{
${ }^{1}$ Tampere European Council 15 and 16 October 1999, Presidency conclusions, para. 33.

C. Holmsten, LL. M. (Uppsala), Project lawyer

CHolmsten@era.int

1 European Private Law Section, Academy of European Law (ERA), Trier, Germany
} 
awareness and knowledge of the different legal instruments among legal practitioners. According to the Commission's new EU Justice Agenda for 2020, strengthening trust, growth and mobility within the Union is the main challenge to be tackled. ${ }^{2}$ Complex and incompatible legal or administrative systems in the Member States would hinder persons and businesses to operate all across the EU, therefore making it difficult for them to exercise their rights. ${ }^{3}$

The need for judicial training of legal practitioners has been made clear as one of the main priorities, as $35 \%$ of the 2014-2020 Justice Programme's overall budget has been set aside to "to support and promote judicial training, including language training on legal terminology, with a view to fostering a common legal and judicial culture". ${ }^{4}$ The Commission also stated in 2011 that half of the 700000 legal practitioners should be trained in EU law or in the national law of another Member State by 2020. In 2014, more than 132000 legal practitioners had received training, showing that the goal set by the Commission is fully achievable. ${ }^{5}$ By continuing to offer judicial training to legal practitioners, ERA is contributing to the achievement of this goal.

The European Commission has identified judicial training as one of the "key elements" for building trust in EU-wide justice, and that legal language training is a "precondition to effective contacts across Member States, which are in turn the cornerstone for judicial cooperation". 6 As cases involving cross-border elements require a close and effective cooperation, legal practitioners across Member States need to be able to communicate in a foreign language with each other. In order to secure an effective judicial cooperation and correct application of the European legal instruments, sufficient language skills among national legal practitioners are essential.

Seeking to address the lack of sufficient legal and language skills among legal practitioners, ERA launched in 2015 a project named "Enhancing judicial cooperation in civil matters: Organization of a series of interactive language training events". The project will run for 24 months, starting from 1 December 2015, and its main objective seeks to address the need of providing effective and practical European judicial training to national judges. A series of 8 language training events will take place during the entire duration of the project. The main priority during these seminars will be to develop and enhance the English language skills of the participants. Legal terminology of the applicable EU Civil Justice instruments will be practiced, as well as other aspects of performing judicial cooperation, such as filling in relevant forms. National legal practitioners will also receive some in-depth legal training in

${ }^{2}$ Communication from the Commission to the European Parliament, the Council, the European Economic and Social Committee and the Committee of the Regions of 11 March 2014, The EU Justice Agenda for 2020 - Strengthening Trust, Mobility and Growth within the Union, COM(2014) 144 final, Chap. 3.

${ }^{3}$ Tampere European Council 15 and 16 October 1999, Presidency conclusions, para. 28.

${ }^{4}$ See Annex of Regulation (EU) No 1382/2014 of the European Parliament and of the Council of 17 December 2013 establishing a Justice Programme for the period 2014 to 2020, OJ L 354 of 28 December 2013, pp. 73-83.

${ }^{5}$ Final report by European Commission, European Judicial Training 2015, p. 2.

${ }^{6}$ Communication from the Commission to the European Parliament, the Council, the European Economic and Social Committee and the Committee of the Regions as of 13 September 2011, Building trust in EU-wide Justice: A new dimension to European Judicial training, COM(2011) 551 final, pp. 5-6. 
one of the two selected EU legal instruments in the field of judicial cooperation in civil matters.

For this project, ERA has developed two different training programmes: one for cross-border civil litigation (focusing on Brussels Ia), and the other for European family law (Brussels IIa). The legal training will be carried out by legal experts, experienced in providing judicial training. The linguistic training will be carried out by linguist experts who will use language training manuals, specifically created for this project. The training will mainly focus on legal terminology in EU civil law, written and oral comprehension and pronunciation. From this, participants will increase their ability of understanding the EU civil law instruments and gain confidence when handling cross-border cases in the future.

As already mentioned, the chosen legal instruments are Regulation No 1215/2012 (Brussels Ia) ${ }^{7}$ and Regulation No 2201/2003 (Brussels IIa). ${ }^{8}$ They have been chosen due to their practical relevance for national judges. A body of uniform rules governing the jurisdiction of courts in cross-border disputes and the recognition and enforcement of such judgments has been in place in the EU since the Brussels Convention of 27 September 1968. The Regulation marked the need for a close judicial cooperation and has since then been revised several times. One of the objectives of Brussels Ia Regulation is to further simplify the movement of judgments between the Member States as in the abolishment of the exequatur, and to make sure that lis pendens is dealt with more efficiently within the Member States.

Brussels IIa seeks to help international couples to resolve cross-border disputes concerning custody over their children and their divorce. The Regulation sets out rules for determining which court has jurisdiction for dealing with matrimonial matters and parental responsibility, as well as provisions for making it easier to recognize and enforce judgments issued in one EU country to another. Brussels IIa also presents new provisions regarding child abduction, which expand and take precedence over the 1980 Hague Convention ${ }^{9}$ in cases between the contracting Member States of the EU.

Both Regulations have been identified as the most suitable legal instruments at EU level for interactive language training, as they specifically establish the need of close and effective judicial cooperation. Brussels Ia obliges national judges to communicate with judges from other Member States. ${ }^{10}$ Brussels IIa states that direct communication is required for the transfer of a case or for the return of an abducted child. ${ }^{11}$ Therefore, the need for national judges to be able to communicate in a foreign language (usually in English) with their colleagues across the EU is essential in order to understand the provisions of the Regulations.

\footnotetext{
${ }^{7}$ Regulation (EU) No 1215/2012 of the European Parliament and of the Council of 12 December 2012 on jurisdiction and the recognition and enforcement of judgments in civil and commercial matters, OJ L 351 of 20 December 2012, pp. 1-32.

${ }^{8}$ Council Regulation (EC) No 2201/2003 of 27 November 2003 concerning jurisdiction and the recognition and enforcement of judgments in matrimonial matters and the matters of parental responsibility, repealing Regulation (EC) No 1347/2000, OJ L 338 of 23 December 2003, pp. 1-29.

${ }^{9}$ Convention of 25 October 1980 on the Civil Aspects of International Child Abduction.

${ }^{10}$ See, e.g. Art. 29 on declining jurisdiction and Art. 30 on staying of proceedings.

${ }^{11}$ See Art. 15 and Art. 11 (6-7).
} 
Another outcome of this project is the development of training materials for future language trainings in the field of judicial cooperation in civil matters. In creating these language manuals, ERA can contribute to a sustainable approach to legal language training, as these manuals can be used for future training events. Furthermore, these seminars aim at engaging participants in discussions on the proper application of the legal instruments and to promote an exchange of best practices and knowledge. To increase the confidence of national legal practitioners while they are dealing with cases with cross-border elements is crucial. It is also important to enable participants to create contacts between their European colleagues in order to create a true development of a European judicial area. Judicial training gives the opportunity for legal practitioners to trust and get to know other countries' legal systems, and to promote better cross-border cooperation.

The target group of the project is national judges, as they have become the frontline judges of EU law. ${ }^{12}$ As the legal instruments at EU level specifically require the use of direct judicial cooperation and communication, national judges are best fitted to receive judicial training in the field of EU law. The language training plays a vital role in this project, as it will enable the judges to fully handle the increasing number of cases with cross-border elements. The project, with its total of 8 training events, will offer national judges across the EU the unique opportunity to receive tailormade English language training through an interactive method. During the seminar, the judges will also be able to benefit from in-depth training in one of the main EU legislative instruments in the area of judicial cooperation in civil matters.

The maximum group of participants during these seminars will be restricted to 26 judges. The programme for each seminar will offer the participants a mixture of different training methods, varying from lectures and interactive workshops. During several sessions, the participants will be divided into two groups, based on their strengths and weaknesses in the English language. These smaller groups will guarantee that the language training will be able to very much adapt to individual needs. The concept with the division into two smaller groups will also allow parallel sessions during which one group can receive language training and at the same time the other group receives legal training. All in all, 210 judges, dealing with civil law from 8 different Member States, will be educated within the frame of the project. There is also a dedicated project webpage containing information about the project, its events as well as related links, etc. ${ }^{13}$

During this project, ERA is cooperating with 11 different judicial schools with the aim of reaching a truly pan-European dimension. In order to make sure that national judges from all parts of the EU will be able to benefit from the training that ERA provides, the partners are originating from 8 different member States. ${ }^{14}$ All the judicial schools have experience in providing training at national level and together with their experience, ERA will be able to offer high-level judicial training to national judges.

\footnotetext{
${ }^{12} \mathrm{COM}(2011) 551$ final, p. 2.

${ }^{13}$ For further information about the seminars, please visit the project's webpage: https://www.era.int/ ?125943\&en.

${ }^{14}$ The participating Member States are: DE, ES, FR, HU, HR, LT, PL and RO.
} 